\title{
GAMBARAN PENEMUAN KASUS BARU TUBERKULOSIS DI WILAYAH KERJA PUSKESMAS CIRIMEKAR KABUPATEN BOGOR TAHUN 2019
}

\author{
Elka Aulia Putri Samudra ${ }^{1)}$, Suci Pujiati ${ }^{2)}$, dan Rachma Hidana ${ }^{3)}$
}

\footnotetext{
${ }^{1)}$ Konsentrasi Manajemen Pelayanan Kesehatan (MPK), Program Studi Kesehatan Masyarakat, Fakultas Ilmu Kesehatan, Universitas Ibn Khaldun Bogor. Email: elkaauliaputrisamudra@gmail.com

${ }^{2}$ Konsentrasi Manajemen Pelayanan Kesehatan (MPK), Program Studi Kesehatan Masyarakat, Fakultas Ilmu Kesehatan, Universitas Ibn Khaldun Bogor. Email: pujiati.suci@gmail.com

${ }^{3)}$ Konsentrasi Manajemen Pelayanan Kesehatan (MPK), Program Studi Kesehatan Masyarakat, Fakultas Ilmu Kesehatan, Universitas Ibn Khaldun Bogor. Email: rachma.hidana@gmail.com
}

\begin{abstract}
Abstrak
Berdasarkan data laporan program penanggulangan tuberkulosis, di Puskesmas Cirimekar ditemukan pada tahun 2018 sebesar 39,1\%. Tuberkulosis (TB) telah ada selama ribuan tahun yang lalu dan tetap menjadi masalah kesehatan utama secara global. Penelitian ini bertujuan untuk Memperoleh informasi penyebab rendahnya cakupan penemuan kasus baru TB di wilayah Puskesmas Cirimekar Kabupaten Bogor tahun 2019. Penelitian ini menggunakan metode kualitatif dengan cara wawancara mendalam dengan informan sebanyak 10 orang yang terdiri dari Wakil Supervisor Tuberkulosis Dinas Kesehatan Kabupaten Bogor dan pegawai di Puskesmas Cirimekar dengan menggunakan pedoman wawancara.Wawancara dilakukan dengan bantuan recorder, pulpen dan buku catatan.Penelitian ini melakukan pengumpulan data secara langsung atau data primer dan telaah dokumen atau data sekunder. Hasil penelitian menunjukan bahwa input yang terdiri dari sumber daya manusia sudah mencukupi pelatihan sudah dilakukan, anggaran sudah mencukupi, sarana dan prasarana sudah mencukupi, kebijakan menggunakan Peraturan Menteri Kesehatan No 67 tahun 2016 tentang Penanggulangan Tuberkulosis, dan standar operasional prosedur penemuan Suspek Tb sudah ada. Begitu juga dengan proses perencanaan program, penemuan pasien Tb secara aktif dan pasif, pengawasan dan evaluasi untuk program sudah di lakukan,struktur dibentuk. Untuk ouput didapatkan hasil CDR sebesar 39,1\%. Menganalisis program Tuberkulosis di Puskesmas Cirimekar dengan pendekatan sistem yang terdiri dari input, proses dan output. Kesadaran petugas kesehatan Puskesmas Cirimekar untuk lebih menguatkan diagnosa di dalam Puskemas Cirimekar dan Memperluas lintas sektoral dan meningkatkan kesadaran petugas Kesehatan Puskesmas Cirimekar.
\end{abstract}

\section{Kata Kunci :Kasus Baru, Tuberkulosis, Puskesmas}

\section{Pendahuluan}

Pembangunan kesehatan pada hakekatnya adalah upaya yang dilaksanakan oleh semua komponen Bangsa Indonesia yang bertujuan untuk meningkatkan kesadaran, kemauan, dan kemampuan hidup sehat bagi setiap orang agar terwujud derajat kesehatan masyarakat yang setinggi-tingginya, sebagai investasi bagi pembangunan sumber daya manusia yang produktif secara sosial dan ekonomis. Keberhasilan pembangunan kesehatan sangat ditentukan oleh kesinambungan antar upaya program dan 
sektor, serta kesinambungan dengan upayaupaya yang telah dilaksanakan oleh periode sebelumnya. (Kemenkes RI, 2015)

Tuberkulosis (TB) telah ada selama ribuan tahun yang lalu dan tetap menjadi masalah kesehatan utama secara global. Yang menyebabkan 10 juta orang setiap tahunnya mengalamai kesehatan yang buruk dan merupakan salah satu dari sepuluh penyebab utamakematian di seluruh dunia. Selama 5 tahun terakhir, telah memimpinpenyebab kematian dari agen infeksi tunggal, peringkat di atasHIV / AIDS. Ini terlepas dari kenyataan bahwa, dengan diagnosis yang tepat waktudan pengobatan yang benar, kebanyakan orang yang mengembangkan penyakit TB bisa disembuhkan. (WHO, 2017)

Secara global pada tahun 2016 terdapat 10,4 juta kasus insiden TBC (CI 8,8 juta - 12, juta) yang setara dengan 120 kasus per 100.000 penduduk. Lima negara dengan insiden kasus tertinggi yaitu India, Indonesia, China, Philipina, dan Pakistan. Sebagian besar estimasi insiden TBC pada tahun 2016 terjadi di Kawasan Asia Tenggara (45\%) dimana Indonesia merupakan salah satu di dalamnya dan 25\% nya terjadi di kawasan Afrika. Badan kesehatan dunia mendefinisikan negara dengan beban tinggi/high burden countries (HBC) untuk TBC berdasarkan 3 indikator yaitu TBC, TBC/HIV, dan MDRTBC.Terdapat 48 negara yang masuk dalam daftar tersebut.Satu negara dapat masuk dalam salah satu daftar tersebut, atau keduanya bahkan bisa masuk dalam ketiganya. Indonesia bersama 13 negara lain, masuk dalam daftar HBC untuk ke 3 indikator tersebut. Artinya Indonesia memiliki permasalahan besar dalam menghadapi penyakit TBC. (WHO, 2017)

Jumlah kasus baru TB di Indonesia sebanyak 420.994 kasus pada tahun 2017 (data per 17 Mei 2018). Berdasarkan jenis kelamin, jumlah kasus baru TBC tahun 2017 pada laki-laki 1,4 kali lebih besar dibandingkan pada perempuan. Bahkan berdasarkan Survei Prevalensi Tuberkulosis prevalensi pada laki-laki 3 kali lebih tinggi dibandingkan pada perempuan. Begitu juga yang terjadi di negara-negara lain. Hal ini terjadi kemungkinan karena laki-laki lebih terpapar pada fakto risiko TBC misalnya merokok dan kurangnya ketidakpatuhan minum obat. Survei ini menemukan bahwa dari seluruh partisipan laki-laki yang merokok sebanyak $68,5 \%$ dan hanya $3,7 \%$ partisipan perempuan yang merokok. (Kemenkes RI, 2018)

Laporan dari puskesmas menyebutkan bahwa jumlah penderita TB Paru BTA (+) di Kabupaten Bogor tahun 2017 sebanyak 2.820 orang ditambah dengan penderita yang dilaporkan oleh RS Paru Dr. M. Goenawan Partowigdo sebanyak 333 orang , RSUD Ciawi sebanyak 103 orang, RSUD Cibinong sebanyak 46 orang,RS Dhuafa sebanyak 77 orang, RS Sentra Medika sebanyak 15 orang, RSU MH Thamrin sebanyak 78 orang, RSIA Mary CH sebanyak 2 orang, Klinik DR Katili (DPS) sebanyak 3 orang dan lapas kabupaten bogor sebanyak 3 orang sehingga total 3.841 orang $(\mathrm{CDR}=73,88 \%)$, angka ini masih belum mencapai target SPM sebesar $100 \%$. Target penemuan penderita BTA (+) berdasarkan hasil survey prevalensi Kabupaten Bogor adalah 155 / 100.000 penduduk. (Profil Kesehatan Dinas Kesehatan Kabupaten Bogor, 2018)

Berdasarkan data laporan program penanggulangan tuberkulosis, di Puskesmas Cirimekar ditemukan pada tahun 2018 sebesar $39,1 \%$, angka ini masih belum mencapai target pencapaian yang diatur dalam peraturan Menteri Kesehatan RI No. 741/MENKES/PER/VII/2008 tentang Standar Pelayanan Minimal di Bidang Kesehatan di Kabupaten/Kota sebesar $80 \%$ dan menurut kementerian kesehatan sebesar 90\%. (Laporan 
program tuberculosis dan Buku Profil Kesehatan Kabupaten Bogor, 2018)

Tujuan penelitian ini adalah Memperoleh informasi penyebab rendahnya

\section{Metode}

Penelitian ini merupakan penelitian kualitatif dengan pendekatan studi kasus. Populasi dalam penelitian ini yaitu pegawai puskesmas Cirimekar. Sampel didasarkan pada 2 kriteria yaitu informan inti yaitu Petugas yang terlibat dalam kegiatan program penanggulangan Tuberkulosis sedangkan informan kunci yaitu Wakil Supervisor TB Dinas Kesehatan Kabupaten Bogor dan

\section{Hasil}

Input

\section{Sumber Daya Manusia}

Menurut Perarutan Menteri Kesehatan No. 67 tahun 2016 tentang Penanggulangan Tuberkulosis,Standar Ketenagaan TB di Fasilitas Pelayanan Kesehatan di Puskesmas dengan laboratorium yang mampu melakukan pemeriksaan mikroskopis dahak dan menerima rujukan: kebutuhan minimal tenaga pelaksana terlatih terdiri dari 1 dokter, 1 perawat/petugas TB, dan 1 tenaga laboratorium. (Kemenkes, 2016). Informan mengatakan bahwa jumllah yang melaksanakan program TB di Puskesmas sudah mencukupi, seperti berikut yang diungkapkan sebagai berikut :

"Sudah cukup, ada dokter, petugas lab sama program" (II)

"Menurut saya sudah lebih dari cukup, jumlah orang ya bukan kualitas dari itu yahh kalo jumlah orang mah sudah lebih dari cukup." (I/ $)$ cakupan penemuan kasus baru $\mathrm{Tb}$ di wilayah Puskesmas Cirimekar Kabupaten Bogor tahun 2019.

Perawat pemegang program TB di Puskesmas Cirimekar.

Sampel yang telah digunakan, berjumlah 10 orang informan. Penelitian ini menggunakan teori pendekatan sistem yang terdiri dari input, proses dan output. Instrumen penelitian yang digunakan dalam penelitian ini berupa pedoman wawancara dengan cara wawancara mendalam.

Hal ini sudah sesuai dengan SDM di Puskesmas Cirimekar dimana SDM di Puskesmas Cirimekar terdiri dari 2 dokter, 1 perawat/Petugas TB dan 2 tenaga Laboratorium. Jumlah ini sudah disesuaikan dengan lembar observasi. Namun setelah dianalisis terlihat bahwa empat informan mengatakan sudah cukup dan tiga informan mengatakan belum memenuhi standar jumlah SDM untuk pelaksanaan penanggulangan TB.

Menurut Keputusan Menteri Kesehatan Republik Indonesia Nomor 364/Menkes/Sk/V/2009 TentangPedoman Penanggulangan Tuberkulosis (TB) dimana dalam penanggulangan TB ini minimal tenaga pelaksana terlatih terdiri dari 1 dokter, 1 perawat/petugas TB, dan 1 tenaga laboratorium. (Kemenkes, 2009). informan mengatakan bahwa mereka telah mengikuti pelatihan, seperti yang diungkapkan sebagai berikut:

"Dokter sudah, petugas TB sudah, petugas lab nya juga sudah, kapan ya?kalau ga salah 2016 coba nanti ditanyakan lagi." (II) 


\section{“Dulu udah, tahun 2008” (I}

Hal ini sudah sesuai dengan hasil penelitian bahwa yang harus melakukan pelatihan adalah minimal dokter, perawat/Petugas TB dan tenaga Laboratorium. Namun setelah dianalisis sebanyak dua informan sebagai tenaga yang menjalankan program TB mengatakan bahwa mereka belum mengikuti pelatihan dari provinsi atau dari Puskesmas. Dua informan ini adalah kepala puskesmas dan dokter poli umum, yang seharusnya diikut sertakan dalam pelatihan tentang TB untuk memaksimalkan pencapaian penemuan kasus baru tuberkulosis di Puskesmas Cirimekar. Tetapi delapan informan mengatakan bahwa telah mengikuti pelatihan baik yang diadakan oleh provinsi maupun dinas kesehatan Kabupaten bogor yang terakhir dilaksanakan pada tahun 2018 .

\section{Sarana dan prasarana}

Dari hasil penelitian melalui wawancara mendalam dan disertakan dengan lembar observasi yang sudah dilakukan sebanyak enam informan mengatakan hal yang sama bahwa untuk sarana dan prasana yang tersedia untuk penemuan kasus baru TB sudah cukup dan menunjang, baik secara logistik, non logistik dan fasilitas. Dimana apabila dilihat dari logistik seperti Obat Anti Tuberkulosis (OAT) Puskesmas Cirimekar telah menyediakan OAT yang mencukupi untuk pengobatan pasien penderita TB. untuk non logistik atau bahan-bahan seperti Reagensia, Pot Dahak, Kaca sediaan, Oli Emersi, Ether Alkohol, Tisu, Sarung tangan, Lysol, Lidi, Kertas saring, Kertas lensa,TB.01 s/d TB.13, Masker bedah.Respirator N95, mikroskop binokuler, Ose, Lampu spiritus/bunsen, Rak pengering kaca sediaan (slide), Kotak penyimpanan kaca sediaan (box slide), Safety cabinet, Lemari/rak penyimpanan OAT,buku pedoman, buku panduan, buku petunjuk teknis, leaflet, brosur, poster, lembar balik, stiker dan fasilitas seperti ruang laboratorium, ruang pembuangan dahak, ruang konsultasi program $\mathrm{TB}$, ruang penderita MDR yang ada di Puskesmas Cirimekar sudah cukup untuk pelayanan program Penanggulangan TB. Sedangkan satu informan mengatakan bahwa sarana dan prasana belum mencukupi dilihat dari jumlah masker yang dibagikan untuk diduga penderita TB. Upaya untuk mengatasi hambatan kurangnya masker yang berkaitan dengan penemuan kasus baru TB bahwa untuk memilih pasien yang sudah mendekati TB baru diberi masker. Informan mengatakan bahwa sarana dan prasarana sudah cukup seperti yang diungkapkan sebagai berikut :

\section{"Sudah cukup." (II) \\ "Sarana dan prasarana secara fisik sudah cukup walaupun ada perbaikan perbaikan." (I 3$)$}

Menurut Azis, S, M.J. Herman dan Mun'im A Kemampuan tenaga dalam membuat perencanaan obat yang baik dapat mencukupi kebutuhan dalam memberikan pengobatan. (Azis, S., M.J. Herman dan Mun'im, 2005)

\section{Anggaran}

Pembiayaan kegiatan program TB, saat ini didapatkan dari sumber pembiayaan melalui anggaran pemerintah baik APBD sebesar Rp. 631.796.000,-, BOK besar dari dana APBN sebesar Rp. 8.100.000 maupun hibah dari organisasi KNCV Rp. 25.000 per orang untuk transport kegiatan pengiriman pemeriksaan TCM dan sebesar Rp. 150.000,per orang untuk kegiatan pendampingan. Nominal tersebut sudah disesuaikan dalam Keputusan Bupati Bogor No. 900/43 4 /KPTS/PER-UU/2018 Tentang standar satuan 
harga perjalanan dinas jamuan akomodasi pengembangan sumber daya manusia dan pemeliharaan kendaraan tahun anggaran 2019.

Hal ini dibenarkan oleh informan yang mengatakan bahwa pembiayaan program TB didapatkan dari APBN, APBD, dan hibah Seperti yang diungkapkan sebagai berikut :

"Untuk anggaran kita menggunakan
APBD." (II)

“Dari BOK.”(致)

"Anggaran cukup bagus kan di danai oleh apa KNCV ya kalau ga salah.” (I4)

\section{Kebijakan}

Kebijakan dalam program penanggulangan Tuberkulosis masih diatur dalam Peraturan Menteri Kesehatan No 67 tahun 2016 tentang Penanggulangan TB dimana didalam Peraturan tersebut menjelaskan dari mulai SDM, pelatihan pembiayaan, sarana dan prasarana, prosedur baik dalam penemuan kasus TB secara aktif maupun sesara pasif.(Kemenkes, 2016) Seperti yang diungkapkan oleh dua informan sebagai berikut :

"Tetap menggunakan acuan permenkes 67. " $\left(\boldsymbol{I}_{1}\right)$

"iya disini masih menggunakan permenkes 67 itu pasti itu pasti” (I $\left.\boldsymbol{I}_{2}\right)$

Dari hasil penelitian yang sudah dilakukan sebanyak dua informan mengatakan hal yang sama bahwa untuk kebijakan di Puskesmas Cirimekar melaksanakan program TB sesuai dengan peraturan menteri kesehatan No 67 tahun 2016 tentang Penanggulangan Tuberkulosis sama seperti yang dikatakan oleh Wakil supervisor
Tuberkulosis Dinas Kesehatan Kabupaten Bogor dan petugas Program TB di Puskesmas Cirimekar.

\section{SOP}

Standar Operasional Prosedur (SOP) merupakan suatu pedoman atau acuan untuk melaksanakan tugas pekerjaan sesuai denga fungsi dan alat penilaian kinerja instansi pemerintah berdasarkan indikator-indikator teknis, administratif dan prosedural sesuai tata kerja, prosedur kerja dan sistem kerja pada unit kerja yang bersangkutan. (Tjipto Atmoko, 2011)

Dalam suatu program atau suatu pekerjaan yang dilakukan baik diintansi pemerintahan maupun swasta di haruskan ada standar operasional prosedur. seperti yang diungkapkan oleh enam informan yang terdiri dari, kepala puskesmas, dokter, dan petugas program TB sebagai berikut:

"Ada semua lengkap karena puskesmas ini kan sudah akreditasi." (I,

“Pasti adalah ada SOP ada SK.” (I $\boldsymbol{I}_{3}$

Setelah di lakukan penelitian dengan wawancara mendalam dan disesuaikan dengan lembar observasi dimana Puskesmas Cirimekar ini sudah memiliki Standar Operasional Prosedur yang diungkapkan oleh 6 informan yang terdiri dari Kepala Puskesmas, dokter, Petugas program TB dan Petugas Laboratorium.

\section{Proses}

\section{Perencanaan Program Penanggulangan TB}

Dalam perencanaan harus Berbasis data, informasi atau fakta yang akurat tentang situasi epidemiologis dan program $\mathrm{TB}$, di susun setiap tahun berdasarkan kebutuhan kegiatan di masing-masing tingkatan (Pusat, Provinsi dan Kabupaten/Kota), dilakukan 
harus efektif, efisien, dan focus pada pencapaian target indikator kegiatan, (Kemenkes, 2016) Perencanaan ini diungkapkan oleh tujuh informan seperti berikut :

\section{"Kalau perencanaan di RUK tuh udah} sesuai sudah berjalan." (I/3)

\section{"ya itu dilihat dari tahun sebelumnya} ya." (I $\mathbf{I}_{4}$

Dari hasil penelitian dengan wawancara mendalam yang sudah dilakukan sebanyak tujuh informan mengatakan bahwa dalam perencanaan penanggulangan TB di Puskesmas Cirimekar melihat pencapaian tahun sebelum nya, melakukan sesuai dengan RUK (Rencana Usulan Kerja), melihat dari kondisi keadaan dari sebelumnya seperti penderita dan kebutuhan reagen, dan menyesuaikan regulasi yang ada di Puskesmas Cirimekar.

\section{Struktur}

Unit kerja paling sedikit harus memiliki tenaga kesehatan dengan kompetensi di bidang kesehatan masyarakat dan tenaga non kesehatan dengan kompetensi tertentu dan Puskesmas harus menetapkan dokter, perawat, dan analis laboratorium terlatih yang bertanggung jawab terhadap pelaksanaan program Penanggulangan TB. (Kemenkes RI, 2016)

Seperti pada gambar diatas, Puskesmas Cirimekar sudah memiliki struktur organisasi seperti yang diungkapkan oleh ke tujuh informan seperti berikut :

$$
\begin{aligned}
& \text { "Pasti sudah ada" (II) } \\
& \text { “Sudah ada." (I } \left.\boldsymbol{I}_{2}\right)
\end{aligned}
$$

Dari hasil penelitian yang sudah dilakukan sebanyak tujuh informan bahwa dalam struktur bahwa sudah ada dan sudah sesuai dengan kompetensi yang di harapkan seperti dokter, petugas program $\mathrm{TB}$ dan petugas laboratorium.

\section{Penemuan Pasien TB secara Aktif}

Penemuan pasien TB secara aktif dan/atau masif berbasis keluarga dan masyarakat, dapat dibantu oleh kader dari posyandu, pos TB desa, tokoh masyarakat, dan tokoh agama. (Kemenkes RI, 2016) seperti yang diungkapkan oleh informan seperti berikut :

\section{"Ya tetap dalam pedoman permenkes 67. " $\left(\boldsymbol{I}_{1}\right)$}

"Belum berjalan maksimal tapi ya kita kana da kader TB terus ya itu euhhh masyarakat juga kan dilibatkan juga sosialisasi kemarin pun ada pertemuan KNCV dengan linsek" (I $\left.\boldsymbol{I}_{2}\right)$

Dari hasil penelitian yang sudah dilakukan sebanyak delapan informan bahwa penemuan pasien TB secara Aktif dilakukan di luar Puskesmas berbasi keluarga dan dibantu oleh kader, dimana apabila ada pasien terduga dengan adanya gejala penyakit Tuberkulosis maka disarankan untuk ke Puskesmas dan apabila memang benar terkena penyakit TB maka dilakukan pengobatan dan sesuai dengan pedoman nasional penanggulangan TB.

\section{Penemuan Pasien TB secara Pasif}

Penemuan pasien TB dilakukan secara pasif intensif di fasilitas kesehatan dengan jejaring layanan TB melalui Public-Private Mix (PPM), dan kolaborasi berupa kegiatan TB-HIV, TB-DM (Diabetes Mellitus), TBGizi, Pendekatan Praktis Kesehatan paru 
$(\mathrm{PAL}=$ Practical Approach to Lung health $)$, ManajemenTerpadu Balita Sakit (MTBS), Manajemen Terpadu Dewasa Sakit (MTDS). (Kemenkes RI, 2016)

Dipuskesmas Cirimekar Penemuan pasien TB secara pasif dilakukan di fasilitas kesehatan seperti yang diungkapkan oleh tujuh informan seperti berikut :

"Ya tetap dalam pedoman permenkes 67. " $\left(\boldsymbol{I}_{1}\right)$

"Di puskesmas sendiri sudah berjalan sesuai SOP." (I $\left.\boldsymbol{I}_{2}\right)$

Menurut hasil wawancara dan disertai dengan lembar observasi yang sudah diisi pada petugas penanggung jawab TB penemuan pasien TB secata pasif yang sudah ditentukan oleh Peraturan Menteri Kesehatan No 67 tahun 2016 tentang Penanggulangan TB, di Puskesmas Cirimekar sudah di lakukan semuaPublic-Private Mix (PPM), dan kolaborasi berupa kegiatan TB-HIV, TB-DM (Diabetes Mellitus), TB-Gizi, Pendekatan Praktis Kesehatan paru (PAL = Practical Approach to Lung health), Manajemen Terpadu Balita Sakit (MTBS), Manajemen Terpadu Dewasa Sakit (MTDS).

\section{Pengawasan dan evaluasi}

Pemerintah dan Pemerintah Daerah sesuai dengan kewenangannya melakukan pembinaan dan pengawasan terhadap penyelenggaraan Penanggulangan Tuberkulosis berdasarkan hasil pemantauan dan evaluasi. (Kemenkes RI. 2016)

Monitoring dan evaluasi seharusnya dilakukan melalui kegiatan supervisi (on the job training) dan pertemuan triwulanan di berbagai tingkat. (Kemenkes, 2017) Seperti yang diungkapkan oleh informan seperti berikut :
"Pernah yah.pengawasan paling kita tidak tidak yah melakukan supervisi ya tidak ada pengawasan secara khusus setiap puskesmas kita sama ratakan dengan puskesmas lain paling ya supervisi itu dan monitoring evaluasi" $\left(I_{1}\right)$

"Kan kalau kita ada pertemuan khusus ya dipuskesmas rapi, rapi itu rapat pagi hari, lalu ada riang rapat siang hari kemudian ada lokmin, lokmin bulanan dan triwulan yang dikecamatam disana ada pun dari dinas ada rutin, kemarin juga ada tuh pak aan turun. ya mengenai $T B$ " $\left(\mathbf{I}_{2}\right)$

Dari hasil penelitian dengan wawancara mendalam sebanyak tujuh informan bahwa pengawasan dan evaluasi telah dilakukan di Puskesmas Cirimekar baik dari Dinas Kesehatan maupun dari Puskesmas Cirimekarnya sendiri.Untuk kegiatan monitoring dan evaluasi yang dilakukan dipuskesmas Cirimekar baik dari Dinas Kesehatan terlaksana secara maksimal atau pada tahun 2018 telah dilakukan supervisi lebih dari empat kali.Namun, untuk pengawasan laboratorium atau Crosscheck di Puskesmas Cirimekar pada tahun 2018 belum sepenuhnya mengikuti kegiatan crosscheck tersebut dimana dalam kegiatan kegiatan Crosscheck harus dilakukan sebanyak 4 kali dalam setahun.

\section{Output}

Dari data petugas program penanggulangan TB dan wakil supervisor Dinas Kesehatan Kabupaten Bogor didapatkan hasil jumlah kasus TB yang diobati dan dilaporkan di wilayah kerja puskesmas Cirimekar pada tahun 2018 sebanyak 103 orang dan perkiraan jumlah semua kasuss TB pada tahun 2018 menurut 
Dinas Kesehatan Kabupaten Bogor di Puskesmas Cirimekar adalah 263 orang.

Rumus :

Jumlah semua kasus TB yang diobati dan dilaporkan di

$\underline{\text { Wilayah kerja Puskesmas dalam kurun waktu }}$ satu tahun X 100\%

Perkiraan jumlah semua kasus TB dalam kurun waktu satu tahun

\section{Kesimpulan}

Penelitian ini dilakukan untuk menganalisis program Tuberkulosis di Puskesmas Cirimekar tahun 2019. Maka kesimpulan yang didapat disampaikan adalah

1. Input dalam penemuan kasus baru Tuberkulosis di Puskesmas Cirimekar Terdiri dari SDM, sarana dan prasarana Anggaran, kebijakan, SOP sudah ada dan mencukupi.

2. Memperoleh informasi mengenai proses dalam penemuan kasus baru Tuberkulosis di Puskesmas Cirimekar yang terdiri dari struktur sudah dibentuk, perencanaan,

$$
\begin{aligned}
& =\frac{103}{236} \times 100 \% \\
& =39,1 \%
\end{aligned}
$$

Didapatkan CDR di Puskesmas Cirimekar pada tahun 2018 sebesar 39,1\% dimana Standar Pelayanan Minimal di Bidang Kesehatan di Kabupaten/Kota sebesar $80 \%$ dan menurut kementerian kesehatan sebesar 90\%, Maka CDR di Puskesmas Cirimekar masih di bawah standar dari yang sudah di tetapkan.

penemuan Pasien TB secara aktif dan pasif, pengawasan dan evaluasi program sudah dilakukan namun belum optimal

3. Output dalam penemuan kasus baruTuberkulosis di Puskesmas Cirimekar didapatkan jumlah CDR di Puskesmas Cirimekar sebesar 39,1\%. 


\section{Daftar Pustaka}

[1] Atmoko, Tjipto. (2012). Standar Operasional Prosedur (SOP) dan Akuntabilitas Kinerja Instansi Pemerintah. Jakarta: Rieneka Cipta.

[2] Awusi RYE, Yusrizal Djam'an Saleh dan Yuwono Hadiwijoyo. (2009). faktor- faktoryang mempengaruhi penemuan penderita TB parudi Kotapalu Provinsi Sulawesi Tengah. 24 Januari 2019. https://jurnal.ugm.ac.id/bkm/article/vie w/3565

[3] Azis, S., M.J. Herman, \& Mun'im, A. (2005). Kemampuan Petugas MenggunakanPedoman Evaluasi Pengelolaan Dan Pembiayaan Obat. 04 April 2019. file:///C:/Users/WIN\%207/Downloads/3 385-1458-1-PB.pdf

[4] Azwar, Azrul. (2010). Pengantar Administrasi Kesehatan. Jakarta: Binarupa Aksara Publisher

[5] Basrowi\& Suwandi. (2008). Memahami Penelitian Kualitatif. Jakarta: Rineka Cipta.

[6] Bagong, Suyanto. (2005). Metode Penelitian Sosial. Jakarta: Kencana Prenada Media Groupp.

[7] Departemen Kesehatan, (2003). Surveilans Epidemiologi Penyakit (PEP) Edisi I, Jakarta: Ditjend P2PL Depkes RI

[8] Djojodibroto, Darminto. (2007). Respirologi (Respiratory Medicine), Jakarta: Buku Kedokteran EGC.

[9] Faletehan, Aun Falestien. (2014). Pengantar Ilmu Manajemen.

[10] Gunawan, Imam. (2017). Metode Penelitian Kualitatif Teori dan Praktik.Jakarta : Bumi Aksara.

[11] Hudoyo, Ahmad. (2008). Tuberkulosis Mudah Diobati. Jakarta: Fakultas Kedokteran Universitas Indonesia
[12] Insani, Istyadi. 2010. Pengembangan Kapasitas Sumber Daya Manusia Daerah Daam Rangka Peningkatan Transparansi dan Akuntabilitas Pengelolaan Keuangan Daerah. Jakarta: Sekolah Tinggi Ilmu Administrasi Lembaga Administrasi Negara.

[13] Kementerian Kesehatan. (2011). Pedoman Nasional Pengendalian Tuberkulosis.Jakarta.

[14] Kementerian Kesehatan. (2014). Panduan Pengelolaan Logistik Program Pengendalian Tuberkulosis.

[15] Kementerian Kesehatan. (2015). Rencana Strategi 2015-2019.

[16] Kementerian Kesehatan, (2016). Permenkes 67 tahun 2016 tentang Penanggulangan TB.

[17] Kementerian Kesehatan, (2017). Modul Kebijakan Penanggulangan TB. Laksmi, Fuad dan

[18] Budiantoro. (2008). Manajemen Perkantoran Modern. Jakarta: Pernaka.

[19] Martha, Evi. (2016). Metodologi penelitian kualitatif untuk bidang kesehatan, Jakarta : PT Raja Grafindo Persada.

[20] Mack, Natasha. (2005). Qualitative Research Methods: A Data Collector's Field Guide, USAID, USA.

[21] Moekijat. (2008). Adminitrasi Perkantoran. Bandung: Mandar Maju.

[22] Novanty, Fenilla. (2015). Evaluasi Input Sistem Surveilans Penemuan Suspek Tuberkulosis (TB) Di Puskesmas Wilayah Kerja Dinas Kesehatan Kabupaten Magelang.26 Maret 2019. https://lib.unnes.ac.id/20583/1/6411410 048-S.pdf

[23] Nugraini K, Cahyati W dan Farida E. (2015). Evaluasi input capaian case detection rate (cdr) tb paru dalam 
program penanggulangan penyakit tb paru (p2tb) puskesmas tahun 2012 (studi kualitatif di kota semarang). 24 Januari

2019.

https://journal.unnes.ac.id/sju/index.php lujph/article/view /5191

[24] Nuri Anggraeni dan Pujiyanto. (2014). Analisis Manejemn Program TB Paru Di Puskesmas Kecamatan Kemayoran Jakarta Pusat Tahun 2014.26 Maret 2019.

http://lib.ui.ac.id/naskahringkas/201606/S56120-Nuri\%20Anggraeni

[25] Priyadi, Slamet. (2003). Analisis Beberapa Faktor yang Berhubungan dengan Kejadian TB Paru BTA (+) Di Kabupaten Wonosobo. 29 Januari 2019. http://eprints.undip.ac.id/14360/1/2003 MIKM1957.pdf

[26] Pemerintah Kabupaten Bogor. (2018). Standar satuan harga honorarium, perjalanan dinas, jamuan, akomodasi, pengembangan sumber daya manusia dan pemeliharaan kendaraan tahun anggaran 2019.

[27] Sailendra, Annie. (2015). LangkahLangkah Praktis Membuat SOP. Cetakan Pertama.Yogyakarta : Trans Idea Publishing.

[28] Standford T. Shulman, John P. Phair,M.D. dan Herbert M. Sommers, M.D. (1994). Dasar Biologis dan Klinis Penyakit Infeksi Edisi Keempat.Yogyakarta: Gadjah Mada University Press.

[29] Sukmadinata, N.S. (2011). Metode Penelitian Pendidikan. Bandung: Remaja Rosadakarya

[30] Sugiyono.(2011). Metode Penelitian Kuantitatif, Kualitatif dan $R \& D$. Bandung: Afabeta
[31] T.M, Marrelli, (2000). Buku Saku Dokumentasi Keperawatan Edisi 3, Jakarta : Buku Kedokteran EGC.

[32] Virandola. (2011). Analisis Penemuan Kasus Suspek Tuberkulosis Di Kecamatan Taman Sari Kota Administrasi Jakarta Barat. 29 Januari 2019.

http://lib.ui.ac.id/file?file $=$ digital/20290 396-T\%2029578-

Analisis\%20penemuan-full\%20text.pdf

[33] WHO. (2017). Global Tuberculosis Report .

[34] WHO (2009). Bulletin of the World Health Organization.

[35] WHO (2009). TB Impact Measurement: Policy and recommendations for how to assess the epidemiological burden of TB and the impact of TB control.

[36] WHO. (2014). The Use of Delamanid in The Treatment of Multidrug-Resistant Tuberculosis, Interimpolicy guidance, Geneva, Switzerland.

[37] WHO.(2017). Infodatin Tuberkulosis 2018.

[38] Widoyono. (2005). Penyakit Tropis Epidemiologi, Penularan, Pencegahan dan Pemberantasannya. Jakarta : Erlangga.

[39] Wijayanti. Rossalina Adi. (2016). Analisis Faktor Manajemen Di Puskesmas Dalam Meningkatkan Case Detection Rate (Cdr) Tuberkulosis. 24 Januari 2019. https://publikasi.polije.ac.id/index.php/j urnal_kesehatan/article/view/342

[40] Wiwit Aditama, Zulfikar Zulfikar dan Baning R. (2009). Evaluasi Program Penanggulangan Tuberkulosis Paru di Kabupaten Boyolali. 24 Januari 2019. http://journal.fkm.ui.ac.id/kesmas/articl e/view/33 